„Bohemistyka” 2020, nr 3, ISSN 1642-9893

\title{
$\begin{array}{lllllll}\mathbf{K} & \mathbf{R} & \mathbf{O} & \mathbf{N} & \mathbf{I} & \mathbf{K} & \mathbf{A}\end{array}$
}

Wojciech JÓŹWIAK

DOI: $10.14746 /$ bo. 2020.3 .11

Uniwersytet im. Adama Mickiewicza

\section{Alfons Maria Mucha i czechosłowackie banknoty}

Keywords: Czech kultur, Czechoslovakian numismatics, Art Nouveau, history Slowa kluczowe: kultura czeska, numizmatyka czechosłowacka, secesja, historia

\section{Abstract}

The very first banknotes of the newly created Czechoslovakia were designed by Alphonse Mucha. This outstanding Art Nouveau artist used them as medium, through which he could induce the national identity preservation of his compatriots, by referring to both national and induce the national identity preservation of his compatriots, by referring to both national and
Slavic symbolism. Symbolism of the designed notes clearly rooted in Slavic tradition and history in an obvious manner relates to Mucha's artistic interests evidently expressed in the cycle The Slav Epic.

Pierwsze banknoty nowopowstałego państwa czechosłowackiego zaprojektowane przez Alfonsa Muchę stały się dla tego wybitego secesyjnego artysty doskonałym środkiem przekazu, za pośrednictwem którego mógł, odwołując się zarówno do symboliki narodowej jak i ogólnosłowiańskiej, wpłynąć na utrwalenie tożsamości narodowej rodaków. Wyraźnie zakorzeniona $\mathrm{w}$ tradycji $\mathrm{i}$ historii słowiańszczyzny symbolika zaprojektowanych banknotów w oczywisty sposób nawiązywała do zainteresowań artystycznych projektanta wyrażonych dobitnie w cyklu Epopeja Słowiaństwa.

Každý národ má umění, jako má svou řeč. Jeho tradice není majetkem jedgeno (J. Mucha 1982, s. 363)

Monety, a także w późniejszym okresie również i banknoty (które pojawiły się na terenie Europy dopiero w wieku XVII) pełniły na przestrzeni wieków niezwykle ważna rolę bardzo efektywnego mass medium, służacego przekazywaniu zakodowanej w nich informacji (Kiersnowski 1988, s. 16). Było to medium, które jak charakteryzuje Ryszard Kiersnowski, stanowiło bezkonkurencyjny środek upowszechniania informacji, utrzymujący swój prymat aż do czasu wynalezienia druku. Przekaz realizowany był za pomoca dwóch środków wyrazu - obrazu i pisma, stosowanych zarówno razem jak i z osobna, w zależności od czynników charakterystycznych dla danej 
epoki, kraju bądź kręgu cywilizacyjnego. Umieszczane na tym samym znaku pieniężnym przedstawienia ikonograficzne oraz dłuższe lub krótsze teksty cechował różnorodny stosunek wzajemny. Ich przekaz mógł pozostawać całkowicie zbieżny - wyrażający w odmienny sposób tę sama treść, komplementarny - uzupełniający się, mogły takżeprzekazywać treść całkowicie odmienną (Kiersnowski 1988, s. 88). Nie zmienia to jednak w żadnym wypadku faktu, iż dzięki umieszczonym na awersie bądź rewersie środkom wyrazu, monety oraz banknoty cechowała niemożliwa do przecenienia, często niepozbawiona elementu propagandowego (bądź wręcz przez niego zdominowana) funkcja informacyjna (poznawcza), pod pewnym względem w wyraźny sposób zbliżająca znaki pieniężne do tekstu literackiego.

Z całą pewnością moneta (banknot), zarówno w przeszłości, jak i obecnie, stanowi specyficzny element dialogu społecznego, jednostronny środek komunikacji pomiędzy władzą i społeczeństwem, a także emitentem i mieszkańcami obcych państw. Ta zdolność docierania do niemal wszystkich kręgów i warstw społecznych pozwala na manifestację, w tym numizmatycznym tekście, treści niejako zaprogramowanych przez emitenta (władce, rząd itd.).

Głównym celem emisji, oczywiście poza ekonomicznym, było zbudowanie za pomocą przemyślanego i zaplanowanego programu „literacko”-ikonograficznego, właściwego obrazu aktualnych wydarzeń, wykreowanie odpowiedniego wizerunku rządzących państwem (koronowanego władcy, przywódców polityczno-państwowych) łączącego w sobie w określonym zakresie elementy świeckie i sakralne, zgodne z aktualnymi trendami ideowo-artystycznymi (patrz np. Garbaczewski 2006). Wykorzystywane do gruntowania postaw patriotycznych znaki pieniężne stały się $\mathrm{z}$ czasem świadectwem tożsamości narodowej i manifestem ideowym projektujących je artystów.

Zarówno monety jak i banknoty pełniły funkcję specyficznego tekstu programowego zawierającego lapidarne informacje przekazując, z punktu widzenia państwowo-politycznego, najistotniejsze treści - odnoszące się do miejsca i daty emisji oraz danych emitenta (czasem także mincerza), zawierały nazwe jednostki monetarnej, imiona ważnych dla państwa i społeczeństwa bóstw, fragmenty odpowiednich tekstów religijnych, oraz inne istotne zwroty i tytuły (Kiersnowski 1988, s. 19). Umieszczane napisy (sentencje) czyniły z nich obiekty użytkowane zarówno w sferze życia publicznego, jak i prywatnego, odgrywające nierzadko istotną rolę, szczególnie w starożytności i wiekach średnich, w sferze związanej z wierzeniami religijnymi, magia i obyczajowościa - w chwilach uroczystych i codzienności, momentach narodzin i obrzędach związanych ze śmiercią.

Umieszczane na monetach i banknotach teksty to bezdyskusyjnie autentyczne zabytki piśmiennictwa ważne dla wielu kultur oraz języków, przez wiele wieków stanowiące, ,jedyne powszechnie dostępne wzory pisma znajdujące się przed oczyma, lapidarne i łatwe do porównywania i rozwiązywania” (Kiersnowski 1988, s. 91).
Oprócz treści o charakterze polityczno-państwowym (świeckim) dotyczącym środowisk rządzących, napisy-znaki oraz dłuższe fragmenty tekstu odnosiły się częstokroć do problematyki religijnej. Odnoszac się do podstawowych kwestii wiary oraz tekstów wezwań i błogosławieństw numizmaty takie zawierały, charakterystyczny dla literatury religijnej, przekaz o charakterze deklaratywno-dewocyjnym, magiczno-praktycznym, a także informacyjnym, gdy przekazywały treści dotyczące świętych patronów, popularnych na danym terenie i w konkretnym czasie (Kiersnowski 1988, s. 303).

Ryszard Kiersnowski analizując okres europejskiego mennictwa średniowiecznego doszedł do uniwersalnego i ponadczasowego wniosku, jednoznacznie wskazującego bliskie relacje zachodzące pomiędzy literaturą i monetami (banknotami) umieszczony na stemplach menniczych oraz drukarskich matrycach materiał literacki i ikonograficzny stanowiąc wierne odbicie epoki, z której pochodzi, jest typowym wytworem jej kultury. To niezwykle ważne źródło archiwalno-dokumentalne, którego „krótkie teksty, proste wyobrażenia, może mało mówiące o poszczególnych monetach, zebrane łącznie daja przecież swoisty wykład ówczesnej wiedzy o świecie i obraz przemian w sposobie widzenia tego świata" (Kiersnowski 1988, s. 421). Charakterystyczny dla numizmatyki ponadczasowy zespół tekstowo-ikonograficzny dotykał na przestrzeni dziejów, podobnie jak tekst literacki, niemal wszystkich podstawowych kategorii i zagadnień polityczno-kulturowych oraz społecznych. „Zabierał głos” między innymi w kwestiach związanych z władzą i podległością, sprawiedliwością, bogactwem oraz bieda, cnotą i grzechem, chciwościa, prawdą i kłamstwem, dobrem i złem, z problemami wiary, magii i kultu religijnego, obyczajów, czasu, znaku, symboli, słowa i pisma, liczby, propagandy, estetyki (Kiersnowski 1988, s. 421), wreszcie z walką o wolność i tożsamość narodową oraz utwierdzaniem odzyskanej niezależności politycznej.

Niezwykle istotnym elementem programu artystycznego Alfonsa Muchy było jego przekonanie o służebnej wobec narodu (mas) roli sztuki i twórcy. Wobec takich pryncypiów oczywistym było dla artysty, że czynnie włączy się w proces formowania nowego, powstałego w 1918 roku czechosłowackiego państwa.

Jako służbę narodowi potraktował (wykonywane pro publico bono), rozpoczęte w 1909 roku prace związane z projektem wystroju Sali Burmistrzowskiej budowanego od 1905 roku w Pradze gmachu władz miejskich (Obecni dům). 18 grudnia 1918 roku, na prośbę zarządu Klubu Czeskich Filatelistów, przedstawił przyjęty do realizacji projekt pierwszego czechosłowackiego znaczka pocztowego przedstawiającego panoramę Hradczan. Logiczną konsekwencją tych prac było sporządzenie projektów banknotów dokonane na prośbę władz powstałego 28 października 1918 roku nowego państwa.

W pierwszym okresie po odzyskaniu niepodległości na terenie Republiki w obiegu były banknoty Banku Austro-Węgier, na które z czasem zaczęto naklejać specjalne 
znaczki (kolky). Dwa z nich, o wartości 1 korony oraz 10 halerzy również zaprojektował Mucha.

Waluta Republiki Czechosłowackiej, dzieląca się na sto halerzy korona, została ustanowiona 15 kwietnia 1919 roku. Do emisji zostały wprowadzone banknoty o nominale $1 \mathrm{Kč}, 5 \mathrm{Kč}, 10 \mathrm{Kč}, 20 \mathrm{Kč}, 50 \mathrm{Kč}, 100 \mathrm{Kč}, 500 \mathrm{Kč}, 1000 \mathrm{Kč}$ oraz $5000 \mathrm{Kč}^{1}$, z których dziesięciokoronowy (stronę odwrotną; Bieniaś 2012), dwudziestokoronowy, stukoronowy i pięćsetkoronowy zaprojektował Alfons Mucha. Tym samym czeski artysta znalazł się w gronie secesyjnych twórców takich jak np. Gustaw Klimt, Koloman Moser, Heinrich Lefter, Arthur Kampf, Paul Thumann czy Józef Mehoffer i Adam Półtawski, którzy projektowali banknoty dla Austro-Węgier, Niemiec i odrodzonej Polski.

Na projektach zaproponowanych przez związanego w latach 1889-1906 z kręgami secesji francuskiej (paryskiej) Muchę, swoje odzwierciedlenie znalazły wszystkie elementy charakterystyczne dla jego artystycznego stylu. W centrum wizji twórczej Muchy znalazła się kobieta:

[...] to ona przykuwa hipnotycznie [...] uwagę swym nieopisanym spojrzeniem, które nie pozwala oderwać oczu, będąc czymś w rodzaju niewypowiedzianej obietnicy - napełniająca błogóci , świadomości [...]. Uroku dodają jej często warkocze, loki, czy spowijające ją pukle włosów, często rozwianych na wietrze, podczas gdy jej głowę otacza aureola. Jest diametralnym przeciwieństwem [...] wszystkich chorowitych, słabujących czy diabolicznych kobiet, które w tym samym czasie zapełniały obrazy Toulouse-Lautreca, [...] Klimta, [...] czy Gauguina (Lipp 2007, s. 13).

Artysta pełnymi garściami czerpał z tradycji bizantyjskiej, celtyckiej, japońskiej, gockiej i żydowskiej oraz słowiańskiej (czeskiej, ale również południowosłowiańskiej) sztuki ludowej. Bogata, charakterystyczna dla secesji ornamentyka kwiatowa i roślinna (najczęściej rośliny o wysmukłych lub wiotkich łodygach), inkrustowana powtarzającymi się motywami symbolicznymi, dominujące, tworzące nastrój ciepła, pastelowe barwy m.in. fiolet, róż, błękit, zieleń i biel, całkowite wypełnienie powierzchni deseniem (horror vacui) oraz czesto stosowana asymetria widoczna w kompozycji dzieła stały się rozpoznawalnymi elementami projektów pierwszych czechosłowackich banknotów.

5 lipca 1919 roku jako pierwszy do obiegu został wprowadzony banknot o nominale 100 koron ((por. fot. 1 i fot 2; honorowany do 31 stycznia 1921). Z braku środków technicznych pierwotnie banknot był drukowany na prywatnych, domowych maszynach drukarskich, które w żadnym stopniu nie mogły zapewnić wykonania nawet najdrobniejszych antyfałszerskich zabezpieczeń. Stąd wykonanie dalszych emisji zlecono firmie American Banknote Company w Nowym Jorku.

Por. https://finance.idnes.cz/prvni-prvorepublikove-papirove-penize-navrhoval-i-alfonsmucha-pxd-/sporeni.aspx?c=A081027_093344_bank_hru [dostęp: 14.10.2018].
Na rewersie umieszczona została nazwa emitenta (REPUBLIKA ČESKOSLOVENSKA) oraz napisana w sześciu językach etnosów zamieszkujących nowoutworzone państwo - czeskim, słowackim, ukraińskim, polskim, niemieckim oraz węgierskim wartość banknotu i nazwa waluty. Podobnie jak na awersie, wszystkie pierwszoplanowe napisy miały kolor czerwony. Szaroniebieskie tło było pełne symboliki odnoszącej się do nowej, słowiańskiej Republiki. Po obu stronach rewersu znalazł się taki sam portret kobiety, Słowianki w chuście na głowie, okolonej bardzo charakterystyczną dla twórczości Muchy aureolą - to podobizna żony artysty, Maruški (22 lata młodszej, z którą artysta ożenił się w 1906 roku). Wizerunki połączone zostały wijącymi się gałązkami lipowymi, na których, pośrodku (pomiędzy podobiznami), z rozpostartymi skrzydłami siedzi sokół, nad którego głowa umieszczone zostało wschodzące Słońce ${ }^{2}$. Pod nim, na obwiedzionym jaśniejszą linią liściu lipy umieszczony został nominał. Rewers zawierał niezwykle czytelne symbole odnoszące się do odrodzenia, powstania czechosłowackiego państwa - sokół symbolizujący pewność siebie i dumę, ale także nadzieję na odzyskanie wolności oraz lipa (jej liście i gałęzie) w słowiańskiej mitologii żeńska zasada bytu, drzewo bóstw miłości i życia rodzinnego, symbol płodności i witalności mający moc ochrony przed złem (Wójtowicz 2018).

Kolejnym banknotem, którego rewers został zaprojektowany przez Alfonsa $\mathrm{Mu}$ chę była pierwsza czechosłowacka dziesięciokoronówka (por. fot. 3) - wprowadzona do obiegu 28 lutego 1920 roku i honorowana aż do 31 maja 1944 roku.

Tym razem jako modelka posłużyła artyście jego urodzona w 1909 roku córka Jaroslava, która została przedstawiona po obu stronach banknotu, na podobieństwo rusałki z rozpuszczonymi włosami i wpiętymi w nie białymi kwiatami (margaretki?), które stały się dominantą motywu zdobniczego rewersu. Tło banknotu stanowiły przeplatające się elementy roślinne, a w centrum po raz kolejny znalazł się, tym razem stylizowany liść lipy, na którym umieszczono nominał. Na rewersie widniała także nazwa emitenta oraz powtórzony w sześciu językach nominał i nazwa waluty.

W 1920 roku wprowadzono także do obiegu banknot o nominale 20 koron (por. fot. 4). Jego awers zdobiły w czterech narożnikach wizerunki głów kobiecych, jakby zaczerpnięte z obrazów Epopei Słowiańskiej.

Sinoniebieskie tło stanowiły motywy roślinne, w środkowej cześci umieszczony został ciemniejszy, horyzontalnie umieszczony owal. W centrum znalazł się beżowy

\footnotetext{
${ }^{2}$ Kolorystyka banknotu może również wskazywać na symbolikę lunarną, w pewnym stopniu powtórzoną wokół głów dziewcząt. Ku takiej interpretacji może skłaniać przypisywanie Musze umieszczania symboliki masońskiej na czechosłowackich banknotach. Mucha wstąpił do Loży podczas pobytu w Paryżu w 1898 roku, a w niepodległej Czechosłowacji został w 1923 roku Suwerennym Wielkim Komandorem Rady Najwyższej Rytu Szkockiego Dawnego i Uznanego Czechosłowacji. Wiẹcej na temat symboli wolnomularskich na czechosłowackich banknotach Stolárova 2013, s. 15.

O wolnomularskiej symbolice księżyca por. np. http://wolnomularstwo.info.pl/index.php/ masonskie-deski/item/569-symbolika-ksiezyca [dostęp: 02.07.2019].
} 
kwadrat z nominałem i nazwą waluty oraz informacjami o przepisach regulujących wprowadzenie waluty, a także ostrzeżenie o karze za fałszerstwo i podpis ministra finansów. W tle umiejscowiony został jasnoczerwony herb Czechosłowacji. W górnej i dolnej części banknotu powtórzono nominał (cyfrą), a po bokach, rozdzielając niejako portrety kobiet w niebieskich prostokątach znalazły miejsce znaki seryjne. Ornamentykę uzupełniły cztery rozety, dwie kwiatowe i dwie z cyfrą 20 , umieszczone wokół środkowego owalu.

Rewers w kolorystyce sinoczerwonej, zawierał nietypowy motyw kompozycyjny - dwukrotnie powtórzoną po bokach banknotu, nakrytą beretem głowę mężczyzny (por. fot. 5). Jest on interpretowany jako francuski legionista (Sém 1977, s. 99), czyli członek sformowanej we Francji w roku 1914 (i biorącej udział w walkach na polach bitew I wojny światowej do 1918 roku) Legii Czechosłowackiej. Można przypuszczać, że jest to mały fragment większej (trudnej do zidentyfikowania) kompozycj (widać dłoń trzymającą drzewiec sztandaru, na którym znajduje się na tarczy herbowej czeski lew). Pośrodku banknotu umieszczony został, skierowany ostrzem ku dołowi, obnażony, spowity w rośliny, miecz symbolizujący zwycięstwo (Sém 1977, s. 99). Także w tym projekcie wyraźnie uwidocznione zostały gałęzie i liście lipy. U dołu w centralnej cześści usytuowany został nominał, wydrukowana na zielono nazwa emitenta oraz powtórzona w sześciu językach wartość banknotu.

W październiku 1919 roku wyemitowano banknot o nominale 500 koron (por. fot. 6), na którego awersie dominowała, odwołująca się do zamierzchłej przeszłości, alegoryczna scena stanowiąca wymowne przedstawienie zakorzenionego w histori marzenia o wolności, które ziściło się na początku XX wieku, przedstawiająca słowiańską rodzinę - kobieta przędąca wełnę, obok której w naczyniu rośnie małe drzewko lipowe oraz mężczyzna pokazujacy dziecku majaczaca w oddali panoramę Hradczan. Oprócz formuł prawniczych, u góry banknotu umieszczono informację o nominale powtórzonym w umieszczonych po bokach okręgach.

Na rewersie, z prawej strony (por. fot. 7) Mucha zaplanował wizerunek kobiety przyozdobionej na głowie wieńcem z kwiatów, konterfekt tożsamy z portretem na banknocie dwudziestokoronowym (górna para), naprzeciwko którego znalazła się, wpisana w okrąg z liści lipy kompozycja herbów Czech (w centrum), Słowacji (nad nim) oraz Moraw i Śląska (po bokach) - znak Legii Czechosłowackiej (utworzonej w Rosji), uznawany w latach 1918-1920 za symbol państwowy. W dolnej części, w kolejnym okręgu, tym razem otoczonym wieńcem ze zbóż, owoców oraz gałęz znalazł się nominał (liczba), powtórzony w prawej i lewej strony w sześciu językach Dominujący motyw stanowiły dwa czarne sokoły, jakby trzymajace się szponami motywu dekoracyjnego banknotu, z uniesionymi skrzydłami, stojące tyłem do siebie, lecz z wygiętymi w swoje strony głowami.

W 1920 roku został wprowadzony do obiegu banknot o nominale 1000 koron (por. fot. 8), który nie był projektowany przez Muchę, jednak artysta miał swój wyraźnie widoczny udział w jego powstaniu. Jednym z elementów kompozycji awersu stał się portret „słowiańskiej księżniczki/wieszczki”. Pierwowzorem był stworzony przez Muchę w 1896 plakat reklamowy oraz logo powstałej w 1868 roku najstarszej czeskiej instytucji finansowej - Banku Ubezpieczeń Slavia. Motyw został powtórzony przez artystę w 1908 roku w namalowanym w USA portrecie przedstawiającym Josephine Crane Bradley (por. fot. 9), córkę Ch. R. Cranea, mecenasa Alfonsa Muchy i sponsora cyklu Epopei Słowiańskiej. Utożsamianie umieszczonego na banknocie wizerunku z amerykańskim portretem jest oczywistym (powielanym bardzo często) błędem, dokładne porównanie trzech wymienionych konterfektów wyraźnie wskazuje, że na stukoronowym banknocie znalazł swe miejsce wizerunek z plakatu reklamowego Banku Ubezpieczeń (por. fot. 10).

„Slavia” była jedynym motywem secesyjnym i jedynym „,czeskim” tego projektu. Pozostałe, autorstwa rytowników American Banknote Company, przypominają stylem dolary amerykańskie.

Po raz ostatni zwrócono się do Muchy z prośbą o przygotowanie projektu banknotu w 1929 roku, gdy secesja była już style passé, a w sztuce królowało art deco. Pomimo tego artysta zaproponował kompozycję wyraźnie nawiązującą do przebrzmiałego i krytykowanego prąu. Zaprojektowana pięćdziesięciokoronówka (por. fot. 11) została wprowadzona do obiegu w 1931 roku i pozostała w nim do 1 listopada 1945.

Kompozycja awersu oparta została na dwóch prostokątach, mniejszym z prawej i większym z lewej strony. W lewym górnym rogu (dominanta mniejszego prostokąa) artysta umieścił, w otoczonym białą, niemal jaśniejącą linią okręgu, ujęta z profilu głowę kobiety z rozwianymi włosami i wpiętymi w nie liśćmi lipy. Pod tą kompozycją znalazł się, ujęty w jaśniejszy kwadrat, nominał i numer seryjny. Całość dopełniały motywy roślinne i zwierzęce. Elementem centralnym większego prostokąta była, wpisana w horyzontalnie usytuowany owal, nazwa nominału oraz waluty. Pod nią znalazł się bardzo rozbudowany tzw. wielki herb państwowy, zaprojektowany przez Alfonsa Muchę i ustanowiony (razem z małym i średnim herbem) 30 marca 1920 roku. Przedstawiał on w centralnej części tarczę herbową, na której w centrum znajduje się herb Czech - stojący na dwóch łapach lew w koronie z podwójnym ogonem, po jego bokach na siedmiu polach umieszczone zostały herby Słowacji (trójwzgórze z wbitym w nie patriarszym krzyżem), Rusi Zakarpackiej (na dwudzielnym polu, po lewej stronie trzy złote pasy, po prawej niedźwiedź wspięty na tylnych łapach), Moraw (orzeł w szachownicę), Śląska (czarny orzeł ze srebrną przepaską i krzyżem na piersi), Ziemi Cieszyńskiej (złoty orzeł), Ziemi Opawskiej (dwupolowy, srebrno-czerwony), Ziemi Raciborskiej (połaczone herby cieszyński i opawski). Tarcze podtrzymują dwa lwy z podwójnymi ogonami stojące na gałązkach lipy oplecionej szarfa z zaczerpniętą z listu Jana Husa dewiza „Prawda zwycięży” („PRAVDA VITĚZI”). Przestrzeń prostokąta wypełnił ornament roślinny i wielokrotnie powtórzony zapisany cyframi nominał. 
Rewers był kompozycyjnym powtórzeniem awersu (por. fot. 12). W małym prostokącie ponownie znalazł się profilowy portret kobiety z liśćmi lipy we włosach oraz wpisany w kwadrat nominał.

W centrum dużego prostokata umieszczona została w owalu scena przedstawiająca na pierwszym planie mężczyznę, robotnika $\mathrm{z}$ atrybutami swego zajęcia kołem zębatym oraz młotkiem ${ }^{3}$. Za nim umieszczona została kobieta, której wizerunek stanowił kolejny portret dorosłej już córki artysty - Jaroslavy, stylizowanej na wiejską dziewczynę. Symbolizować miała ona naturę - trzyma pod pachą snop zboża, w lewej dłoni sierp, a w uniesionej prawej naczynie, z którego wyrasta drzewko lipy. Przedstawienie tej pary to symboliczne połączenie techniki i natury, nowoczesności i tradycji w państwie.

Wokół owalu, w czterech językach (czeskim, niemieckim, węgierskim i ukraińskim) umieszczone zostały napisy informujace o nominale i walucie. Wartość banknotu została także powtórzona w rozetach umieszczonych w czterech narożnikach dużego prostokąta.

Zrealizowane projekty pierwszych banknotów Republiki Czeskiej stały się dla Alfonsa Muchy wspaniałym medium, dzięki któremu mógł przekazać swe idee niewyobrażalnie szerokiemu odbiorcy. Wyłamując się z secesyjnego pesymizmu i strachu przed przyszłością i techniką czeski artysta przekonywał o przyjazności Wszechświata i możności osiągnięcia szczéścia w życiu. Wierzył, że człowiek zaangażowany jest w długą i bolesną walkę, u której kresu czeka uwolnienie się od niedoskonałości i osiągnięcie stanu niebiańskiego ideału. Pomocną rolę w tym procesie odgrywa tzw. wielka dusza świata, objawiająca się w postaci światła i mająca swój wyraz w sztuce (Lipp 2007, s. 13-15). Wizerunki i symbole umieszczone na projektach banknotów, wyraźnie osadzone $\mathrm{w}$ tradycji i historii słowiańszczyzny były efektem fascynacji, u której źródła legł, zamówiony przez rząd CK Austrii, projekt dekoracji pawilonu Bośni i Hercegowiny na Wystawie Swiatowej w Paryżu w 1900 roku. Powstał pean na cześć dążeń Słowian Południowych i ich tradycji, którego owocem był realizowany w latach 1910-1928 wspaniały cykl malarski - Epopeja Słowiańska.

\section{Literatura}

B i e n i á J., 2013, Motywy secesyjne na banknotach Austro-Wegier, Czechostowacji, Niemiec i Polski, Nasze Korzenie" IV, s. 71-76. Online: http://mazowsze.hist.p1/39/Nasze Korzenie/985/2013/36211 [dostep: 14.10.2018].

Garbaczewski W, Wyobrazienia na monetach polskich w dojrzatym średniowieczu, „Biuletyn Numizmatyczny” 2006, nr 2 (342), s. 101-116.

K i e r s n o w s k i R., 1988, Moneta w kulturze wieków średnich, Warszawa.

L i p p R. F., 2007, Alfons Mucha. Czlowiek i jego przestanie, przeł. R. Turczyn, [w:] V. Arwas, A. Dvorák, J. Mičoch, P. Wittlich, S. Mucha, R. R. Lipp, Alfons Mucha, Warszawa, s. $13-21$

${ }^{3}$ To, wraz z kozłem (Bafometem?) umiejscowionym za mężczyzną stanowić miało kolejne nawiązanie do symboliki masońskiej (Stolárova 2013, s. 15).
Much a J., 1982, Alfons Mucha, Praha: Mladá fronta.

Mu ch a S., 2007, Alfons Mucha, Warszawa: PWN

O r m i st on R., 2011, Alfons Mucha i jego świat, Warszawa: Arkady

S é m J., 1977, Papirové penize na územi Ceskoslovenska 1762-1975, Hradec Králové.

S t o lá r o va L., 2013, Alfons Mucha. Umělec a penize, „M\&B. Časopis o mincích, bankovkách a medailích", č. 2, s. 12-15.

U1me r R, 2002, Alfons Mucha 1860-1939. Mistrz Art nouveau, Taschen.

W ó j t o w i c z M., 2018, Etnografia Lubelszczyzny - ludowe wierzenia o drzewach. Online: http://teatrnn.pl/leksykon/artykuly/etnografia-lubelszczyzny-ludowe-wierzenia-o-drze wach/\#charakterystyka-wybranych-drzew-lipa [dostęp: 15.10.2018]. 




Fot. 1. Banknot czechostowacki o nominale 100 koron (awers), emisja z 1919 r. (https://livebid.cz/auctionlaurea_13eA/detail/8085\#)

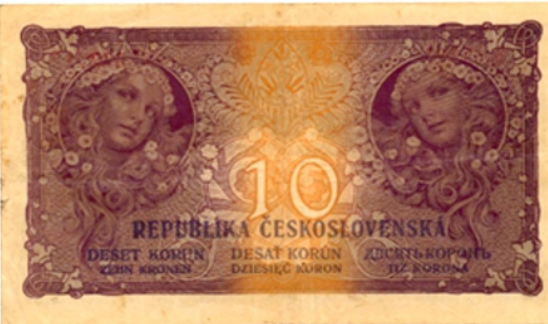

Fot. 3. Banknot czechosłowacki o nominale 10 koron (rewers) emisja z 1920 r. (https://davidse.rajce.idnes.cz/samsu)

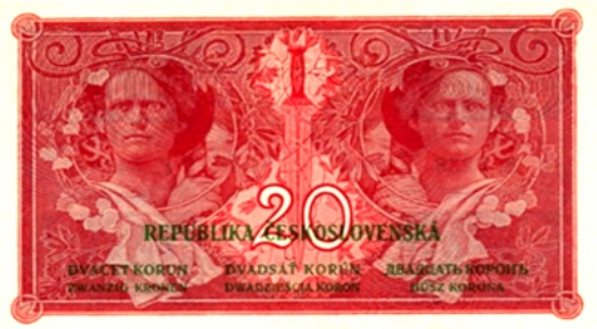

Fot. 5. Banknot czechostowacki o nominale 20 koron (rewers), emisja z 1920 r. (https://www.aurea.cz/Katalog51/051kat3101.htm)

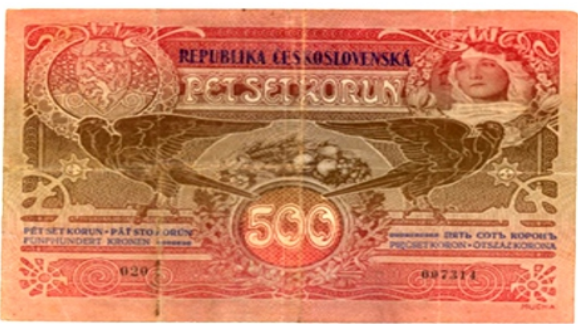

Fot. 7. Banknot czechostowacki o nominale 500 koron (rewers) emisja z 1919 r. (https://aurea.livebid.cz/auction/aurea_77) detail/3344)

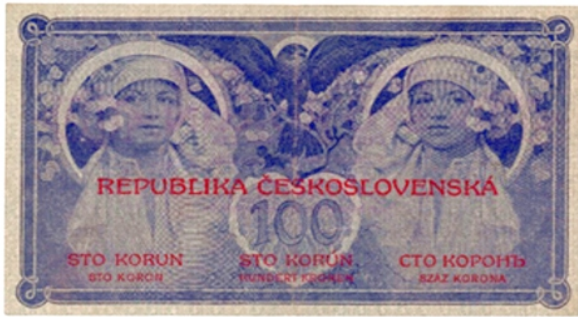

Fot. 2. Banknot czechosiowacki o nominale 100 koron (rewers), emisja z 1919 r. (https://www.gash.cz/1919-1938/nn-11-100-kc-1919

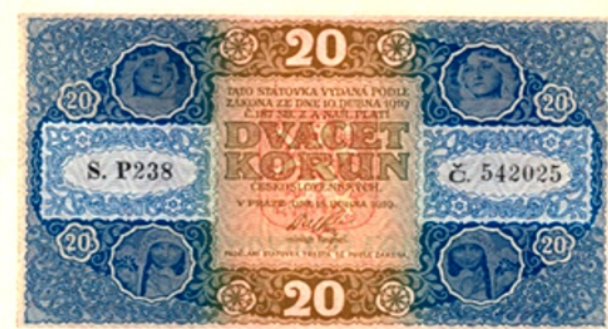

Fot. 4. Banknot czechostowacki o nominale 20 koron (awers) emisja z 1920 r. (https://mww.numisbids.com/n.php?p=lotassid=20028lot=3083)

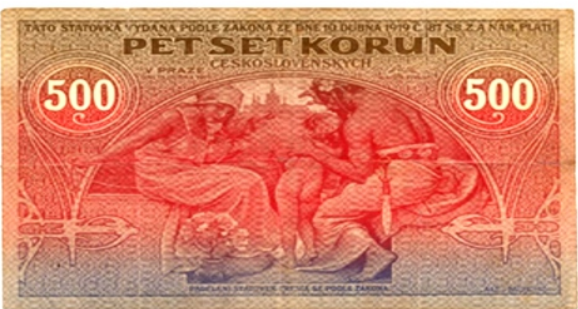

Fot. 6. Banknot czechostowacki o nominale 500 koron (awers), emisja z 1919 r. (https://aurea.livebid.cz/auction/aurea_ 77/detail/3344)

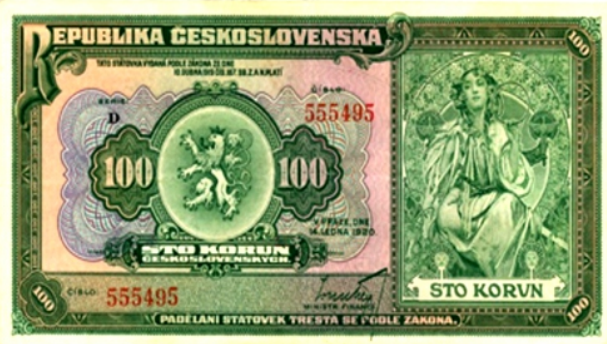

Fot. 8. Banknot czechosłowacki o nominale 100 koron (awers), emisja z 1920 r. (http:/linvesticnisberatelstvi.cz/domains/investicn sberatelstvi.cz/wp-content/uploads/2015/04/100_KČ__1920_lic.jpg)

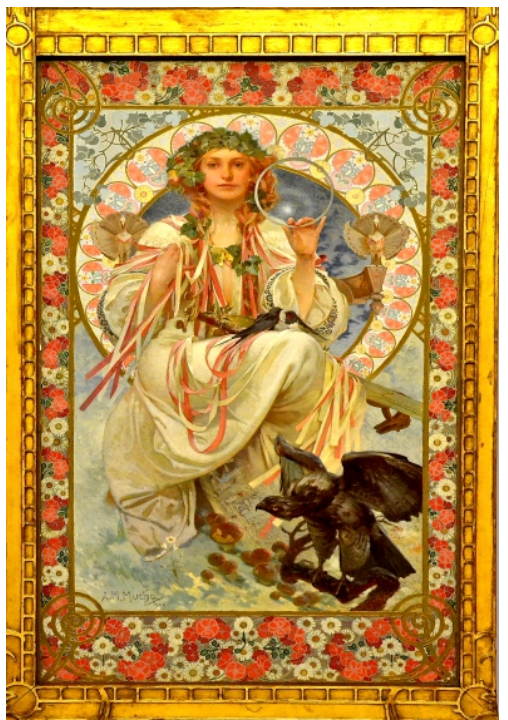

Fot. 9. Portret Josefhine Crane Bradley (https://c2.staticflickr.com/6/5485/ 11329612346_66f149590b_h.jpg)

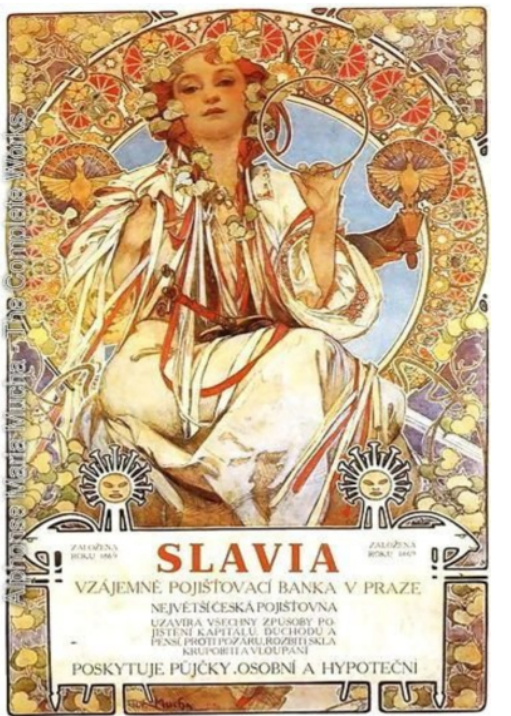

Fot. 10. Plakat reklamowy Banku Ubezpieczeń Slavia (https://www.alfonsmucha.org/thumbnail/135000/ 135474/mini_large/Slavia,-1896.jpg?ts=1459229076



Fot. 11. Banknot czechosłowacki o nominale 50 koron (awers), emisja z 1931 r. (https://www.realbanknotes.com/upload/60/Czechoslovakia_p22s_50_Korun_1929_t.jpg)

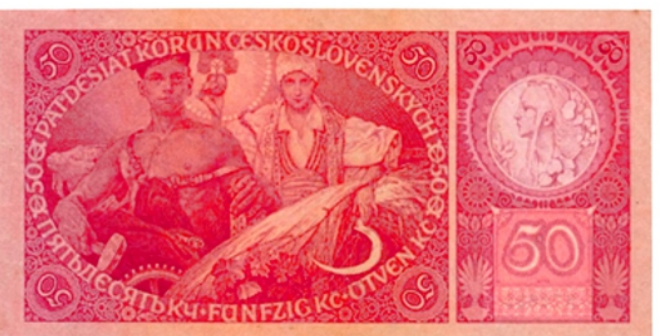

Fot. 12. Banknot czechosłowacki o nominale 50 koron (rewers), emisja z 1931 r. (https://1.allegroimg.com/original/0c76f5/a47f9de649308e50e51776205d01) 